\title{
I. POTASSIUM-ARGON DATING OF GLAUCONITE FROM A GREENSAND DRILLED AT SITE 270 IN THE ROSS SEA, DSDP LEG 28
}

\author{
Ian McDougall, Research School of Earth Sciences, \\ Australian National University, Canberra, A.C.T. 2600
}

Site 270 is located in the southeastern part of the Ross Sea off the Antarctic continent at latitude $77^{\circ} 26.48^{\prime} \mathrm{S}$, longitude $178^{\circ} 30.19^{\prime} \mathrm{W}$ and water depth of 634 meters (Hayes et al., 1973). The hole at this site was drilled to a subbottom depth of 422.5 meters; basement consisting of marble and calc-silicate gneiss of presumed lower Paleozoic age was encountered at 412 meters. Silty clay and claystone and clayey siltstone, ranging from Recent to Oligocene age, was found to a subbottom depth of 384 meters. Between a depth of 384.3 and 385.1 meters, the sediment is a calcareous greensand composed of sand, silt, clay, carbonate, and glauconite (Unit 3) and is considered to have been deposited in a continental shelf environment. Below the calcareous greensand occurs 0.7 meter of carbonaceous sandstone (Unit 4) and 25.3 meters of sedimentary breccia (Unit 5) overlying basement.

A small sample $(39 \mathrm{~g})$ of the calcareous greensand of Unit 3 was made available for $\mathrm{K}$-Ar dating of the glauconite. The sample was carefully crushed and glauconite separated with heavy liquids and a magnetic separator. Two concentrates, each of about $1 \mathrm{~g}$ were obtained; one of these was virtually $100 \%$ grain purity but with about $2 \%$ of clay material adhering to the glauconite grains, whereas the other was less pure, with approximately $8 \%$ of contaminating clay-like material and some quartz. Both concentrates were dated by standard techniques (McDougall, 1966); potassium was determined by flame photometry and argon by isotope dilution using ${ }^{38} \mathrm{Ar}$ as tracer. Prior to argon extraction in the high vacuum line, the glauconite samples were baked at $130^{\circ} \mathrm{C}$. The isotopic composition of the extracted argon was determined in a substantially modified AEI MS10 mass spectrometer which has a 4.2 kilogauss permanent magnet and digital readout.

Results are given in Table 1. Note that the potassium contents of the two samples are virtually identical, and that the duplicate argon determinations on each sample agree to within experimental error. However, the rather impure glauconite concentrate yields a $\mathrm{K}-\mathrm{Ar}$ age of 28.0 m.y., whereas the high purity glauconite gives a significantly younger measured age of $26.0 \mathrm{~m} . \mathrm{y}$. A possible reason for this is that the clay in the impure glauconite concentrate was derived from an older terrain and that all the preexisting radiogenic argon in this component was not lost at the time of deposition of the greensand. Thus the 26.0 m.y. age of the virtually pure glauconite is regarded as the best estimate of the time of deposition of the sediment. However, it should be noted that glauconite commonly yields $\mathrm{K}-\mathrm{Ar}$ ages that are too young due to the ease with which radiogenic argon is lost from this mineral (Hurley et al., 1960; Thompson and Hower, 1973). Although there are insufficient data to check on this possibility in the present case, it is probably reasonable to regard the 26.0 m.y. age as a reliable minimum.

On the physical time scale an age of $26 \mathrm{~m} . \mathrm{y}$. is midOligocene, as the Eocene-Oligocene boundary has an estimated age of 37.5 m.y. (Berggren, 1972), and the Oligocene-Miocene boundary is dated at approximately 22.5 m.y. (Berggren, 1972; Page and McDougall, 1970). This mid-Oligocene age for the glauconite appears to tie in very well indeed with the paleontological estimate of Oligocene for the sediments that occur just above the greensand, suggesting that there is no hiatus between the greensand and the overlying sediments.

\section{REFERENCES}

Berggren, W.A., 1972. A Cenozoic time-scale-some implications for regional geology and paleobiogeography: Lethaia, v. 5, p. 195-215.

TABLE 1

Potassium-Argon Ages on Glauconite Concentrates from DSDP Leg 28, Sample 270-43-6, 125-135 cm (364 m subbottom depth)

\begin{tabular}{|c|c|c|c|c|c|}
\hline $\begin{array}{l}\text { Lab. } \\
\text { No. }\end{array}$ & $\mathrm{K}(\mathrm{wt} \%)$ & $\frac{\text { Rad. }{ }^{40} \mathrm{Ar}}{\left(10^{-6} \mathrm{cc} \mathrm{NTP} / \mathrm{g}\right)}$ & $\frac{100 \mathrm{Rad}^{40} \mathrm{Ar}}{\text { Total }^{40} \mathrm{Ar}}$ & $\begin{array}{l}\text { Calculated } \\
\text { Age (m.y.) } \\
\pm 2 \text { S.D. }\end{array}$ & Remarks \\
\hline $73-1184$ & $5.392,5.389$ & $\begin{array}{l}6.092 \\
6.052\end{array}$ & $\begin{array}{l}48.6 \\
62.4\end{array}$ & $\begin{array}{l}28.1 \pm 0.4 \\
27.9 \pm 0.4\end{array}$ & $\begin{array}{l}\text { Approximately } 8 \% \\
\text { impurities, mainly clay }\end{array}$ \\
\hline $73-1184$ & $5.349,5.376$ & $\begin{array}{l}5.628 \\
5.571\end{array}$ & $\begin{array}{l}02.4 \\
54.3 \\
58.0\end{array}$ & $\begin{array}{l}26.1 \pm 0.4 \\
25.9 \pm 0.4\end{array}$ & $\begin{array}{l}\text { About } 2 \% \text { impurities, } \\
\text { mainly clay }\end{array}$ \\
\hline \multicolumn{2}{|c|}{$\lambda_{\mathrm{e}}=0.585 \times 10^{-10} \mathrm{yr}^{-1}$} & \multicolumn{4}{|c|}{${ }^{40} \mathrm{~K} / \mathrm{K}=1.19 \times 10^{-2}$ atom per cent } \\
\hline
\end{tabular}


Hayes, D.E., et al., 1973. Leg 28 deep-sea drilling in the southern ocean: Geotimes, v. 18, p. 19-24.

Hurley, P.M., Cormier, R.F., Hower, J., Fairbairn, H.W., and Pinson, W.H., Jr., 1960. Reliability of glauconite for age measurement by the $\mathrm{K}-\mathrm{Ar}$ and $\mathrm{Rb}-\mathrm{Sr}$ methods: Am. Assoc. Petrol. Geol. Bull., v. 11, p. 1793-1808.

McDougall, I., 1966. Precision methods of K-Ar isotopic age determination on young rocks. In Methods and techniques in geophysics, vol. 2: New York (Interscience), p. 279304.

Page, R.W. and McDougall, I., 1970. Potassium-argon dating of the Tertiary $\mathrm{f}_{1-2}$ stage in New Guinea and its bearing on the geological time-scale: Am. J. Sci., v. 269, p. 321-342.

Thompson, G.R. and Hower, J., 1973. An explanation for low radiometric ages from glauconite: Geochim. Cosmochim. Acta, v. 37, p. 1473-1491. 